\title{
Application of Fuzzy Cognitive Mapping in Livelihood Vulnerability Analysis
}

\author{
Chrispen Murungweni $^{1,2}$, Mark T. van Wijk ${ }^{1}$, Jens A. Andersson $^{1,3}$, Eric M. A. Smaling ${ }^{4}$, and Ken E. Giller ${ }^{1}$
}

\begin{abstract}
Feedback mechanisms are important in the analysis of vulnerability and resilience of social-ecological systems, as well as in the analysis of livelihoods, but how to evaluate systems with direct feedbacks has been a great challenge. We applied fuzzy cognitive mapping, a tool that allows analysis of both direct and indirect feedbacks and can be used to explore the vulnerabilities of livelihoods to identified hazards. We studied characteristics and drivers of rural livelihoods in the Great Limpopo Transfrontier Conservation Area in southern Africa to assess the vulnerability of inhabitants to the different hazards they face. The process involved four steps: (1) surveys and interviews to identify the major livelihood types; (2) description of specific livelihood types in a system format using fuzzy cognitive maps (FCMs), a semi-quantitative tool that models systems based on people's knowledge; (3) linking variables and drivers in FCMs by attaching weights; and (4) defining and applying scenarios to visualize the effects of drought and changing park boundaries on cash and household food security. FCMs successfully gave information concerning the nature (increase or decrease) and magnitude by which a livelihood system changed under different scenarios. However, they did not explain the recovery path in relation to time and pattern (e.g., how long it takes for cattle to return to desired numbers after a drought). Using FCMs revealed that issues of policy, such as changing situations at borders, can strongly aggravate effects of climate change such as drought. FCMs revealed hidden knowledge and gave insights that improved the understanding of the complexity of livelihood systems in a way that is better appreciated by stakeholders.
\end{abstract}

Key Words: drought; fuzzy cognitive mapping; Great Limpopo Transfrontier Conservation Area; livelihood; southeastern Zimbabwe; vulnerability

\section{INTRODUCTION}

Over the past decades, livelihood analysis has emerged as a powerful participatory approach in poverty analysis and poverty reduction strategies. By integrating different disciplinary perspectives and challenging sectoral approaches, this approach links the particularities of local-level situations of people trying to make a living to wider institutional and socioeconomic dynamics. While livelihood analyses, with a focus on assets and capital, have nevertheless "remained largely focused on a fairly instrumental poverty reduction agenda, framed by economists“ (Scoones 2009), environmental concerns have been influential in these analyses since the late 1980s, as is evidenced by the wellknown sustainable livelihoods framework (SLA; Chambers and Conway 1992). SLA methods have been criticized because of the difficulty to assess pathways of change or trajectories of vulnerability and resilience within households (e.g., Toner 2003).

Sustainability implies that livelihoods are relatively stable and resilient and thus able to cope with shocks and stresses. Assessing the possible effects of such shocks and stresses on different livelihoods at the local level remains an important challenge in the face of wider processes such as climate change and new land-use policies. Resilience thinking, with its origins in ecological systems thinking (Adger 2000, Folke et al. 2002), is increasingly being applied to the study of what are commonly known as social-ecological systems (Folke et al.
2002). Integrating such resilience thinking into participatory livelihood approaches has been labeled a work in progress (Folke 2006, Scoones 2009). Here, we aim to contribute to this integration by evaluating a simple participatory reasoningscheme methodology, called fuzzy cognitive maps (FCM), that enables local people and scientists jointly to assess the effects on different local livelihoods of different future scenarios that people identify.

Many approaches have been used as analytical and participatory methods in livelihoods analysis: agent-based modeling (ABM; Castella et al. 2005, Eakin and Luers 2006), dynamic systems models (DSMs; Dougill et al. 2010), Bayesian belief networks (BBNs; Newton et al. 2006), and more recently, FCMs (Kok 2009). ABM and DSMs typically encounter problems with lack of information to describe the processes they include, are often case specific in structure, and the underlying assumptions of both methods are often hidden in the implementation details (e.g., O'Sullivan and Haklay 2000). BBNs and FCMs have the ability to combine quantitative and quantitative information and have some similarity in the way they use a transparent, graphical representation of the functioning of the system, which can supplement existing, less transparent frameworks that analyze vulnerability (e.g., Fraser 2007, Ericksen 2008).

BBNs have been used in livelihood analysis (Newton et al. 2006, Martínez-Santos et al. 2010), evaluation of forest management (Haas 1991, Crome et al. 1996), and

\footnotetext{
${ }^{1}$ Wageningen University, ${ }^{2}$ Grasslands Research Institute, Zimbabwe, ${ }^{3}$ University of Zimbabwe, ${ }^{4}$ University of Twente
} 
environmental policy studies (Wolfson et al. 1996). A BBN is a graphical model for probabilistic relationships among a set of variables (Pearl 1993, Heckerman 1999) and gives a compact representation of reasoning under uncertainty by making reference to Bayes' rule for computing probabilistic inference (Smid et al. 2010). BBNs offer many advantages. They readily handle incomplete data sets (Heckerman 1999), they concisely represent probabilistic relationships (Cooper 1990, Pearl 1993), and their graphical user interface makes the approach simple to use for non-experts (Smid et al. 2010). Their drawback is that they do not allow for inclusion of direct feedbacks in the analysis, which limits their use in vulnerability assessments. Feedback mechanisms are important in the analysis of vulnerability and resilience of social-ecological systems, and equally in the analysis of livelihoods, particularly if policy makers are to develop options that are well adapted to local conditions (Folke et al. 2002). Here, we use FCMs, a methodology that allows for analysis of both direct and indirect feedbacks and allows further exploration of vulnerabilities of livelihood types to identified hazards.

FCMs use fuzzy-graph structures that represent causal reasoning, allowing systematic causal propagation, in particular, forward and backward chaining (Kosko 1986). Tolman (1948) introduced cognitive maps; their use has origins in politics (Axelrod 1976, Hermann 1978). Kosko (1986) extended their use, which later spread to various fields such as forest management (Mendoza and Prabhu 2006), biological processes occurring at cellular level (Weinreb et al. 2006), and scenario development (Kok 2009). Özesmi and Özesmi (2004) compared FCMs with a dynamic model and found them to be useful in evaluating complex systems. To be able to use FCMs, a qualitative understanding of how elements of a larger structure are related to one another is required (Carley and Palmquist 1992). Relative weights are then used to quantify strengths of causal relationships between the elements (Kosko 1986). The weights are included in a matrix that is used subsequently for scenario analyses.

Here, we use FCM-based scenario analysis to understand the vulnerability of poor rural households to events perceived as hazards. The scientific use of vulnerability has its roots in geography and natural hazards research (Turner et al. 2003, Janssen 2006). The term is now a central concept in a variety of other research contexts such as ecology, public health, development studies (Adger 1999), famine analysis (Watts and Bohle 1993), disaster risk study (Swendsen and Norman 1998, Subcommittee on Disaster Reduction 2003), and notably, social-ecological systems thinking (Berkes 2007). Vulnerability is used here as an attribute of livelihoods and thus emphasizes people and the way they manage their lives.

Our goals were to analyze the functioning of different livelihoods in southeast Zimbabwe and to study the vulnerability of these livelihoods to external changes. This was done using FCMs, allowing us also to assess the usefulness of FCMs in livelihood analysis. We studied a livelihood system at the human-wildlife interface of a semi-arid region in southeast Zimbabwe. This area is part of the Great Limpopo Transfrontier Conservation Area, which includes renowned protected areas such as the Kruger, Gonarezhou, and Limpopo National Parks in South Africa, Zimbabwe, and Mozambique, respectively (see http://www.greatlimpopopark.com/developments/ history.htm). Proposals for land-use change have been made to include more space for wildlife and ecotourism in smallholder farming and livestock areas surrounding these national parks (Dzingirai 2003, Spenceley 2008).

\section{METHODS}

\section{Description of the area}

The case study area is located to the southwest of Gonarezhou National Park in the southeast lowveld of Zimbabwe (Fig. 1). Southeastern Zimbabwe is a drought-prone region more suitable for both livestock and wildlife than for cropping. Local communities depend on livestock as their main source of livelihood, yet it has been argued that tourism with wildlife makes more sense. This situation presents a conflict of interest between several stakeholders on the best land-use options and natural resource conservation strategies. Already there are complex relationships among various subsystems in the area: communal grazing or grazing in the park; water for cattle, people, and wildlife; sorghum cropping or maize cropping; and other issues related to migration, cattle rustling, and hunting or poaching. In this region, the formation of the Great Limpopo Transfrontier Conservation Area, with Gonarezhou National Park on the Zimbabwean side, has brought new challenges to local populations living in or adjacent to the park.

Gonarezhou National park is not only seen as a threat, but is valued by local people for the following resources: forage, game meat, roofing poles from Androstachys johnsonii (Musimbiti, in the local language), mopane worm (Gonimbrasia belina and Imbrasia belina), thatch grass, controled fish ponds, and traditional medicines such as Xeroderris stuhlmannii (Murumanyama, in the local language) used for malaria treatment. The case study area covers $2750 \mathrm{~km}^{2}$ of communal land divided into four wards, with a total of 6400 households made up of 15,940 men and 20,550 women (Central Statistical Office 2002). Mean annual rainfall is $400 \mathrm{~mm}$ but is highly variable in time and space, with a coefficient of variation of 35\% (Cumming 2005). The vegetation of the area is dominated by lowland mopane (Colophospermum mopane) in eutrophic savanna (Cunliffe 1993). Shangaan-speaking people predominate, with Shona and Ndebele speakers as minorities. 
Fig. 1. Location of the study area. Wards 11, 13, 14, and 15 are the communal areas surrounding Gonarezhou National Park and Gonakudzingwa small-scale commercial farms in southeastern Zimbabwe. Representative members who identified livelihood types and constructed corresponding fuzzy cognitive maps reside in the communal areas shown. Wards overlap with ward names given in the legend.

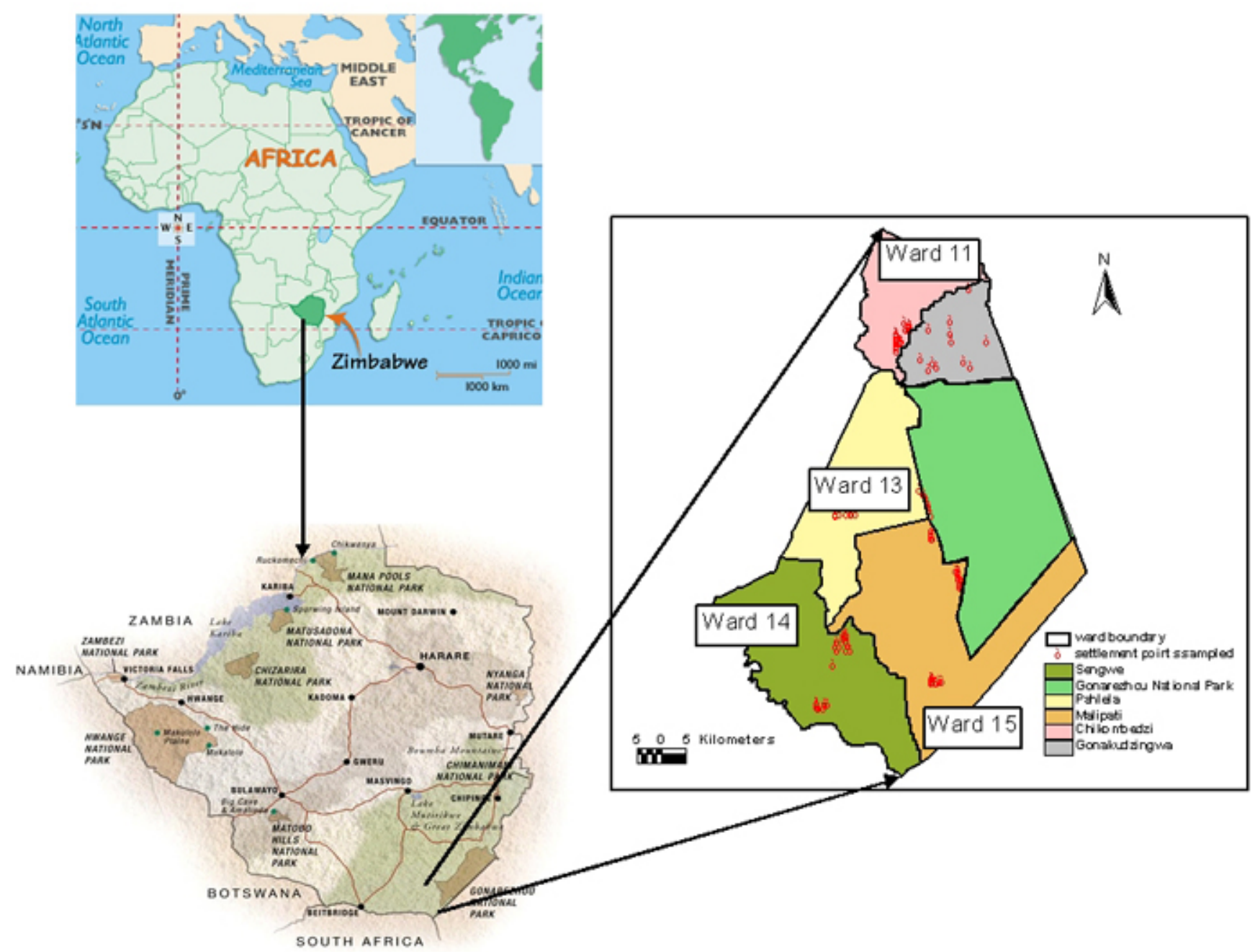

\section{Application of fuzzy cognitive maps}

We used four steps to generate FCMs, each guided by a question:

1. What are the defining variables of different livelihood types that local people and other stakeholders distinguish?

2. How can we understand the structure of each distinguished livelihood type, i.e., the relations between the main assets, activities, and outcomes, as a simple model of interrelated variables?

3. How do local people and other stakeholders perceive the effects of particular hazards on the defining variables of specific livelihood types?
4. Where do particular hazards, e.g., drought or unclear boundaries, affect the constituting variables of the different livelihood types? What consequences does this have for the assets, activities, and outcomes?

\section{Definition of livelihood types}

The research process proceeded through four main stages (Fig. 2). Four groups of individuals were interviewed: local people (those who have a home and live in the study area), informants (people who are knowledgeable about livelihoods in the area but do not necessarily live there), focus group (a group of local people with knowledge about and interest in the particular topic of livelihood research), and stakeholders (organizations and individuals with an interest in natural resources and local livelihoods). Stakeholders could be working for public 
Fig. 2. Four main stages of the research process that was used to understand the vulnerability of different rural livelihoods to hazards in southeastern Zimbabwe. FCM = fuzzy cognitive map.

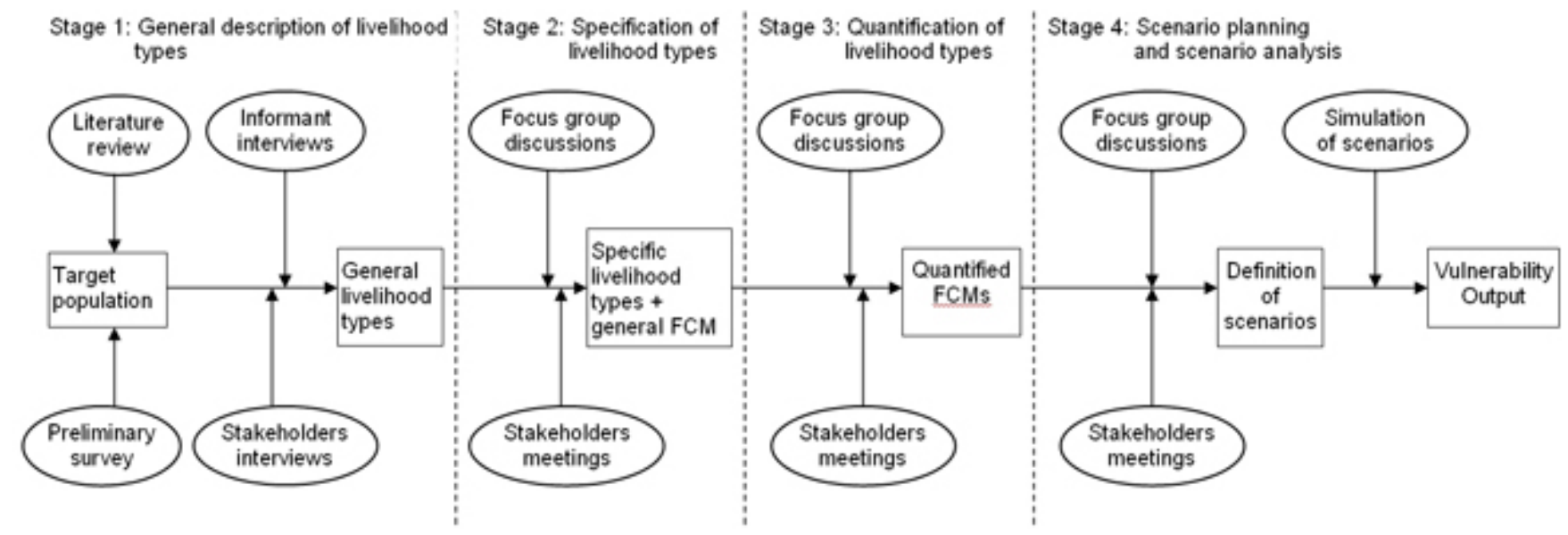

interests such as governments, non-governmental organizations (NGOs), or traditional leaders, or for private interests such as conservancies or safari companies. Current livelihood types were identified based on a preliminary survey $(n=156)$ and two interviews with informants $(n=5)$ and stakeholders $(n=$ 17; Fig. 2, stage 1). During the preliminary survey, stakeholders and informants identified the characteristics that determine different livelihood types. The informants were selected randomly from lists of local people considered typical representatives who were deemed knowledgeable about the livelihoods under investigation. The characteristics identified led to an initial classification of livelihoods that was later refined through group discussions. Based on the initial livelihood classification, representative households $(n=9)$ of each livelihood type identified $(n=3)$ were selected for further study.

\section{Definition of relational diagrams and matrices of fuzzy cognitive maps}

The general livelihood types were refined (Fig. 2, stage 2) by focus groups chosen randomly from lists of household heads of each livelihood type. Each focus group $(n=9)$ drew an FCM diagram to define the structure of its livelihood system. The facilitator showed the groups how to draw a relational diagram to be used within the FCM; then each participant drew an individual diagram on his/her own without interruption. The group then discussed and combined their individual diagrams to make one overall FCM diagram representative of their particular livelihood type. Input by stakeholders from local authorities, NGOs, government officials, and private organizations was used to refine the diagrams in iteration with each group, and the whole group decided on the final structure of the FCM diagram.

\section{Scenario analysis}

Once the FCMs were finalized, stakeholders and focus groups came together to add strengths to the relationships in their maps (Fig. 2, stage 3) and to define possible scenarios to be analyzed using the FCMs (Fig. 2, stage 4). The variables and relationships of the FCM diagram were entered into a matrix. The relative weights given to relationships constitute the elements of the matrix. This means that the matrix is filled with numbers between -1 and 1 with quarterly divisions, where -1 means a very strong negative effect, 0 means no change in effect, and +1 means a very strong positive effect. Next, stakeholders and focus groups defined four scenarios after the effects of the drivers on the system were quantified. The four scenarios were chosen based on current expectations of climate change (i.e., a possible increase in the occurrence of extreme drought events) and policy options in the region, the latter of which is related particularly to migration issues. The four scenarios were: baseline, drought, border, and desirable.

Baseline scenario: Rainfall is normal according to area standards. There are few cases of damage by wildlife from the park. A possible and negotiable system allows local people to cross boundaries to access resources. Institutions are weak due to prevailing political and economic challenges. Political affiliation, for example, determines food access, and cattle rustling has become a complex issue with no solution in sight. In addition, there are few cattle dying, at least half of the planted crops reach harvesting stage, and remittances make a recognizable contribution to household cash and food.

Drought scenario: Rainfall is insufficient for cropping, and there is a high degree of uncertainty as to when it will rain 
next. There is no harvest from upland fields, many cows die, boundary crossing increases, remittances are increasingly important, and food is obtained from across boundaries. The effects of institutions, damage-causing animals outside the park, and unclear boundaries are represented in the same way as in the baseline scenario.

Border scenario: There are many restrictions on and monitoring of movements across boundaries (boundaries are clearer). There is drought, and all crops and many cows die. Boundary crossing is strongly restricted, so there is less inflow of remittances and less food coming from across boundaries. Institutions and damage-causing animals retain the same strength as in the baseline scenario.

Desirable scenario: Rainfall is sufficient for crops, and there is little uncertainty as to when it will rain next. There are few cases of damage by wildlife from the park, and there is a properly defined and targeted compensation strategy for households affected by damage-causing animals. Institutions become stronger in supporting households' access to food. Crops grow well, and all crops that are managed properly give a good harvest. Household cattle ownership increases. Boundaries have an acceptable priority window and mechanism for local people to access resources from either side (boundaries are unclear), and there is increased flow of remittances and food from outside the system boundaries into the household.

After defining the scenarios, the FCM models for the identified livelihood types were run to generate graphs quantifying relative changes in the important livelihood outcomes, cash and food in this case. The influence matrix defined by the focus groups and the stakeholders was the basis for the scenario analysis. To begin this process, an input vector, in which all variables and drivers are given values representing a certain scenario, was multiplied by the matrix. The values of the new output vector were rounded between -1 and 1 (here our approach deviates from the approach used by Van Vliet et al. 2010 and Kok 2009), and constituted a new input vector that was multiplied by the matrix. This process continues until the outcomes of the multiplication and rounding stabilize. The changes in the variables compared with their starting value of zero are interpreted as an increase (if positive) or a decrease (if negative) compared with the original situation. This indicates the importance of different feedbacks within the system under different scenarios.

Total food and available cash in the household were chosen by the focus groups as good indicators of the functioning of each livelihood type. Relative change in total food and available cash was compared with the baseline scenario (set at zero) and quantified. However, it must be noted that the two indicators, i.e., cash and food in the household, are not independent of each other. Families generate cash for buying food and sometimes sell food to get cash.

\section{Sensitivity analysis}

The relative weights given to the relationships between variables of the FCM are by definition uncertain. It is therefore important to assess how robust the outcomes of the scenario analyses are, taking into account this uncertainty. To make this assessment, we performed, for all scenario analyses, a sensitivity analysis in which we randomly varied the values of all weights in the three livelihood matrices within $20 \%$ of their value. In the sensitivity analysis, 1000 new FCM matrices were generated and were run for the scenario analysis of interest. The range of output values at each number of vectormatrix iterations generated were summarized by calculating the standard deviation of the 1000 values. We present the outcomes of the original FCM matrices together with the standard deviation, thereby giving insight into the robustness of the outcomes and how strongly they can be affected by changes in the weights of the relationships.

\section{RESULTS}

\section{Description of livelihood types}

Based on discussions with stakeholders and informants, three key factors were defined, which determined the classification of livelihood types.

5. The value of cattle and relevance of numbers of cattle to a household.

6. The value of cropping and the relevance of vlei areas to a household. Vlei is a term commonly used in southern Africa to mean low lying, gently sloping, treeless land that is seasonally waterlogged with seepage from high ground and rainfall and that contains drainage channels for the removal of excess run-off (Rattray et al. 1953, Ivy 1981). In many parts of central and southern Africa, vlei are also known as dambos.

7. The value of off-farm activities and relevance of remittances to a household.

As a result, three livelihood types were identified: cattle based, crop-cattle based, and non-farm based (Table 1). Cattle-based, crop-cattle-based, and non-farm-based livelihoods constitute $12 \%, 41 \%$, and $47 \%$ of the total local community, respectively $(n=156)$.

\section{Specification of livelihood types}

Focus group discussions defined four building blocks that determined the structure of the different livelihood types: number of cattle in the household, total harvest, available cash, and fees (Fig. 3A). Fees is a variable that defines all payments that the household has to meet to function properly; this includes payments for hospital, grinding meal, school, and transport. After putting in the central building blocks in the overall scheme, the factors determining these key variables were identified (Fig. 3). 
Table 1. General description of livelihood types in southeastern Zimbabwe.

\begin{tabular}{|c|c|c|}
\hline $\begin{array}{l}\text { Livelihood } \\
\text { type }\end{array}$ & General attributes & Coping strategies during drought \\
\hline Cattle based & $\begin{array}{l}\text { - Large kraal } \\
\text { - At least } 20 \text { cattle (median } 30 \text { ) } \\
\text { - At least one granary } \\
\text { - At least two ploughs and a Scotch cart } \\
\text { - Household head usually > } 50 \text { yr old and present } \\
\text { - Household head has primary education level } \\
\text { - Big homestead with at least one brick four-bedroom } \\
\text { house } \\
\text { - Family size average } 15 \\
\text { - Cropping } \\
\text { - No problems sourcing inputs }\end{array}$ & $\begin{array}{l}\text { - Sell cattle (usually in Mozambique) or exchange cattle for } \\
\text { food } \\
\text { - Keep medicines for common diseases of cattle } \\
\text { - Usually rent grazing land from commercial farms of } \\
\text { Gonakudzingwa or migrate with the livestock to specific } \\
\text { distant areas with better grazing and water points } \\
\text { - Loan some cattle to those in need to save on labour } \\
\text { demands for watering cattle using buckets } \\
\text { - Use Zhombwe } † \text { tubers for cattle most affected by drought } \\
\text { - Ferry relief food (for a fee) for those benefitting from } \\
\text { donors } \\
\text { - Hire labor in times of labor constraints }\end{array}$ \\
\hline
\end{tabular}

Crop-cattle based

Non-farm based
- Average size kraal

- $<20$ cattle (median 10)

- At least one granary

- One or two ploughs and a Scotch cart

- Household head 40-50 yr old and present

- Household head has infant to junior primary education level

- Average to small size homestead in poor households

- Family size average 10

- Balance land size for cropping between dry land and vle areas

- Cash for inputs and how to get inputs to farm are problems

- Small or no kraal

- Small thatched round huts to four-bedroom houses with corrugated iron roof, in most cases they have aerials for access to the phone network

- 0 to 10 cattle (median 1 )

- No granary

- Receive remittances

- Crop in wetter areas and have a permanent garden

- Usually no farming equipment (but may own a bicycle)

- Household head < 40 yr old and away most of the time

- Household head has infant education level

- Average to small size homestead in poor households

- Family size average 5
- Sell other livestock species besides cattle in drought years

- Exchange food for cattle in good years

- Buy cattle with extra cash

- Value wetter areas like the Banyeni (fertile, low-lying flat areas that can retain moisture longer than surrounding areas) and the Gumbini (river banks) for cropping

- Borrow cattle from some cattle farmers in times of need

- Harvest wild fruits (especially around Pfungwe, an area with fruit trees along the Limpopo river)

- Dig Zhombwe tubers to feed cattle; rent grazing areas or graze cattle inside park illegally

- Get donor assistance, plant more sorghum, use traditional seeds

- Rent cattle from those with many

- Brew beer or make traditional dishes and invite others neighbours to plough, plant, and eat together at one function

- Increase off-farm activities

- Receive steady remittances

- Hire out labor within and outside Zimbabwe

- Get food aid (only if on the perceived poorer side of this livelihood type

$\dagger$ Zhombwe (Neorautanenia amboensis Schinz) is a perennial, leguminous, mostly erect herb or shrublet producing purple flowers on often trailing stems averaging $0.82 \mathrm{~m}$ in height. It forms an underground tuber of up to $35 \mathrm{~kg}$ ( $70 \%$ water) that has been given to cattle as feed and medicine during droughts in southeastern Zimbabwe since the 1991-1992 drought. 
Fig. 3. Stepwise construction of a cattle-based rural livelihood system in southeastern Zimbabwe using fuzzy cognitive maps. (A) The central building blocks of the overall scheme. (B) Variables affecting the amount of cattle in the household are added to the central building blocks. (C) Variables determining total crop harvest are added. (D) Drivers determining the functioning of the system are added. Gray boxes are key indicators of the functioning of the livelihood; white boxes are variables; white circles are system drivers.

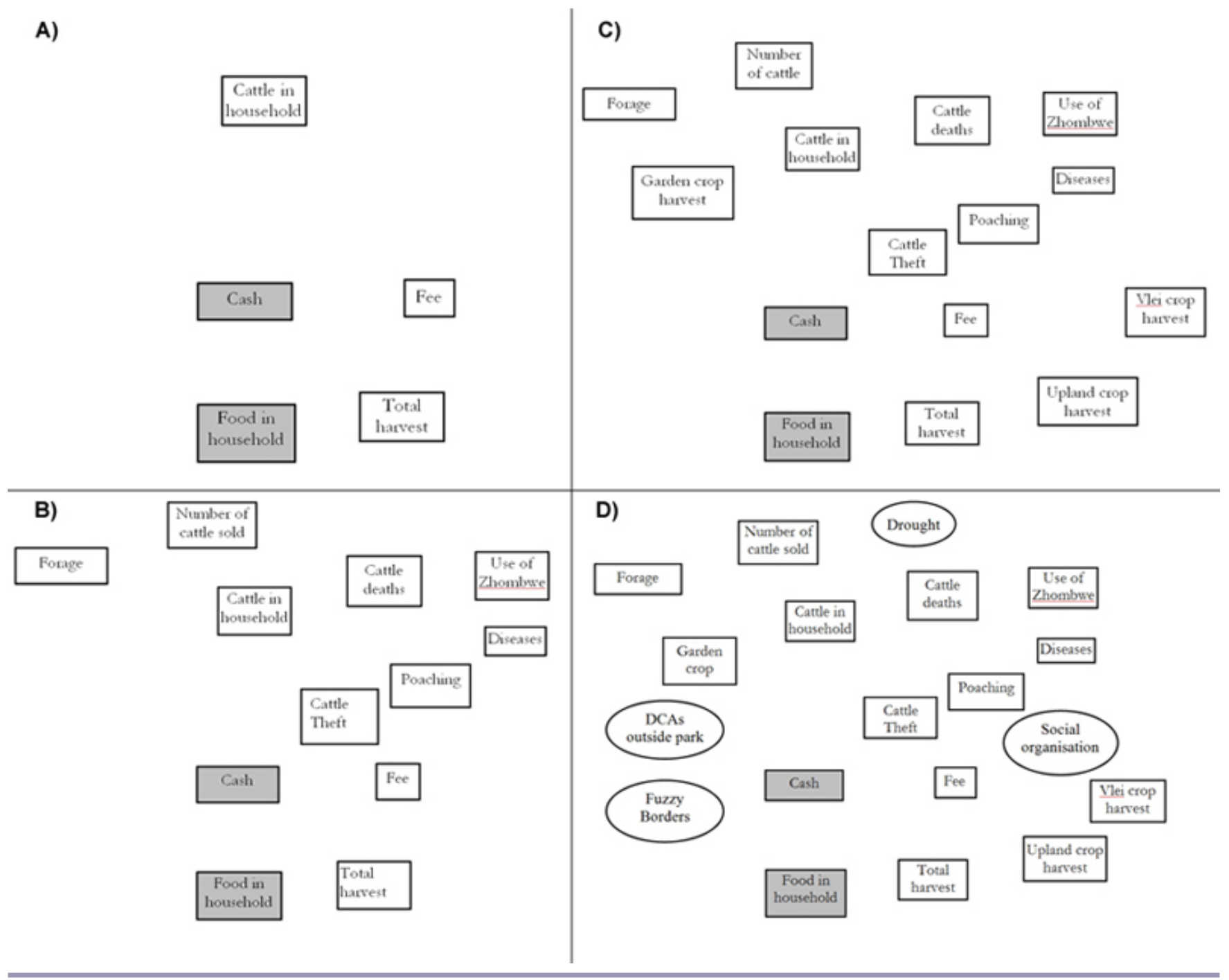

\section{Quantification of livelihood types \\ Cattle-based livelihood system}

The cattle-based livelihood system has a relational diagram of intermediate size (Fig. 4, Table 2). Cash is arguably the most important variable for securing food in a household, basically acquired from the sale of cattle. This cash is mostly used to buy food; some is reinvested in cattle through purchases of drugs to keep them in good health and through direct purchases of cattle after a good harvest. The positive feedback within the system means that more available cash leads to more cattle in the household, resulting in more cattle being sold and more cash available to buy food during drought years. Replacement cattle keep the household going in a good crop production year.

Damage-causing animals outside the national parks reduce the number of cattle directly through depredation and indirectly through disease. Disease affects cattle productivity by reducing the growth rate and reproductive potential. The incidence of disease increases with the severity of drought. Drought reduces forage availability, forcing the already weak animals to graze in contact with soil, exposing them to infectious diseases. To alleviate the loss of cattle due to 
Fig. 4. Fuzzy cognitive map of the cattle-based livelihood type. Grey boxes are key indicators of the functioning of the livelihood; white boxes are variables; white circles are system drivers. Numbers given are influences between factors, where red font indicates negative relationships, and black font indicates positive relationships.

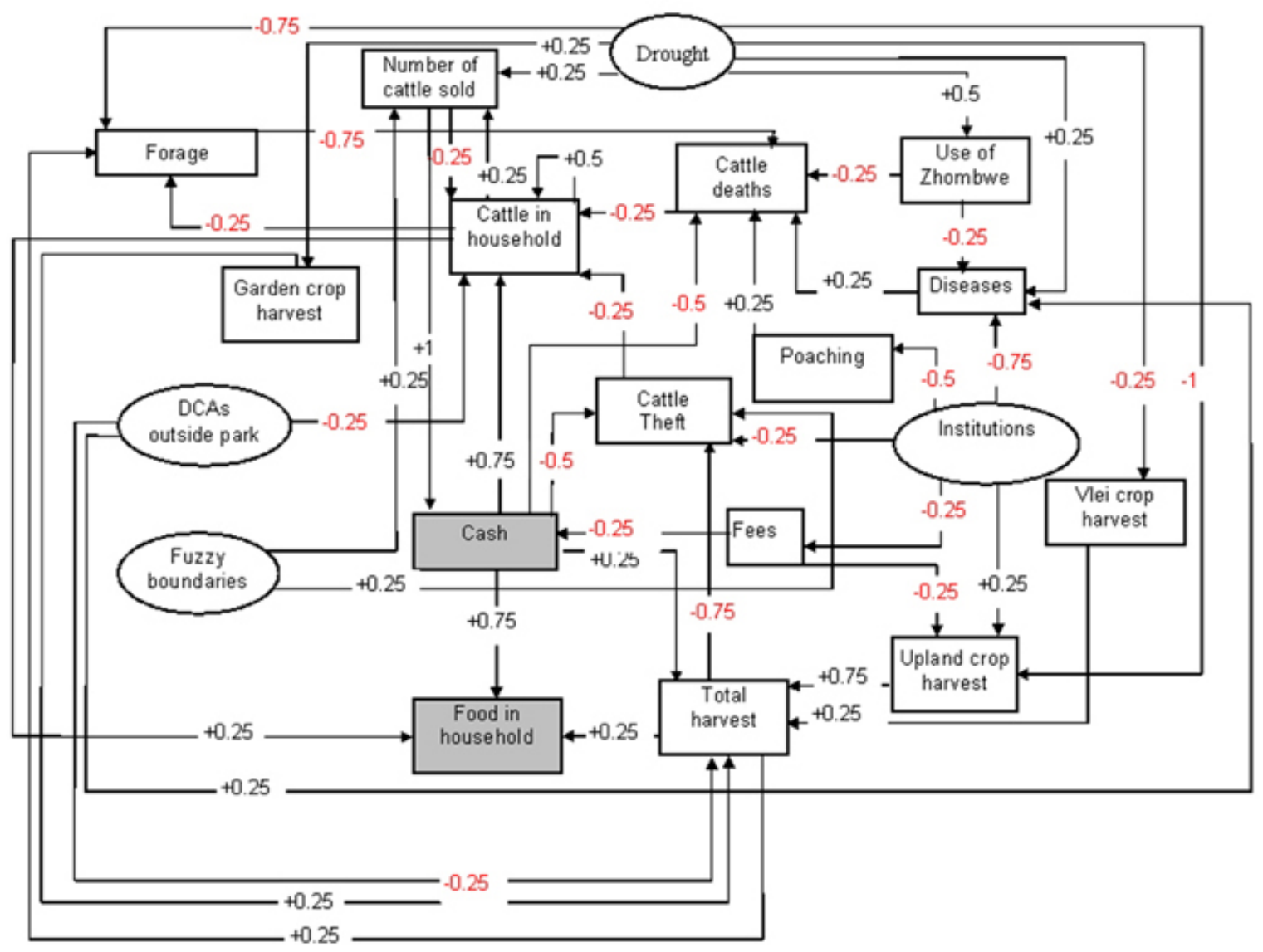

disease, dip-tank committees (a form of social organization) facilitate easier and cheaper access to livestock drugs. In extreme drought years, Zhombwe (Neorautanenia amboensis Schinz)becomes more important; this is a perennial leguminous shrublet that forms underground tubers of up to $45 \mathrm{~kg}$ (74\% water) that are fed to cattle during droughts in southeastern Zimbabwe. Zhombwe is used only to save priority breeding stock from dying because much labor is required to dig up the tubers (C. Murungweni, J. Andersson, M. T. van Wijk, I. Gwitira, and K. E. Giller, unpublished manuscript).

Most of the household food for people in the cattle-based livelihood comes from upland fields, which are strongly and negatively affected by drought.
Table 2. Key characteristics of fuzzy cognitive map diagrams and matrices.

\begin{tabular}{lccc}
\hline \hline Characteristic & \multicolumn{3}{c}{ Livelihood type } \\
\cline { 2 - 4 } & $\begin{array}{c}\text { Cattle } \\
\text { based }\end{array}$ & $\begin{array}{c}\text { Crop-cattle } \\
\text { based }\end{array}$ & $\begin{array}{c}\text { Non-farm } \\
\text { based }\end{array}$ \\
\hline Number of variables & 19 & 21 & 15 \\
Number of connections & 42 & 51 & 38 \\
Sum of all positive connections & 26 & 35 & 27 \\
Sum of all negative connections & 22 & 21 & 14 \\
Density $\dagger$ & 0.12 & 0.13 & 0.18 \\
\hline
\end{tabular}

$\dagger$ Density is the number of connections in the matrix divided by the maximum number of connections possible (Van Vliet et al. 2010). 


\section{Crop-cattle-based livelihood system}

The crop-cattle-based livelihood system has the most variables and connections of the three systems (Fig. 5, Table 2). Total harvest is the most important variable for securing food. Game meat, household gardens, crops from vlei areas, and small stock such as goats and chickens are important for earning cash during droughts. External inputs largely include seed, fences, and diesel for irrigation. Seed, especially groundnut and sometimes maize, is in short supply after a drought year, so people seek seed from outside the livelihood system boundaries. Cattle are mainly used for draft power, so the number of cattle sold is secondary. However, cropping is given less attention as the number of household cattle increase.

Vlei areas are highly valued for food production during drought years (Rattray et al. 1953) when upland fields produce nothing. Damage-causing animals outside the park directly reduce total harvest: elephants and wild pigs invade crop fields, pangolin feed on watermelon, and birds (notably quelea) attack small grain crops. The availability of labor determines the total food harvest. More labor results in more harvest, but more harvest reduces the labor problems of a household: with more food, a household can pay for labor with food.

After a poor harvest, most household members begin the season by working for richer families to obtain food, losing time for their own cropping. This decreases their chances of getting a good harvest during a season that follows a drought year. The recovery path should be long and complex. However, Humwa, a system whereby a household prepares beer and food and then invites neighbors to help with plowing, weeding, or harvesting, smoothens labor peaks, especially for labor-constrained households. Kuronzera/kupfuwisa, a common practice of renting cattle to those in need by those who have many, helps households who lost cattle during a drought and those with no cattle at all to continue cropping. These two practices are good examples of how social arrangements help to reduce drought effects. People with more food can hire labor, and fewer restrictions at boundaries allows for greater flexibility in accessing food across boundaries. More total harvest results in reduced cattle theft, not only because households can employ someone to herd the cattle, but also because fewer people risk stealing.

\section{Non-farm-based livelihood system}

The non-farm-based livelihood system has the fewest variables and connections, although the density is highest of the three FCM matrices (Fig. 6, Table 2). Available cash and donor food are the most important variables for securing food in the household. People with a non-farm-based livelihood system value off-farm activities and remittances, which is a major difference with the other two systems. Drought is the major driver of off-farm activities.
Households belonging to this system do not have cattle of their own and so do not sell cattle. The number of cattle in the household (often obtained through kuronzera/kupfuwisa) plays a role in cropping and in bringing food directly into the household.

Unclear boundaries determine how remittances contribute to cash and food for the household. Remittances decrease with increases in the amount of food harvested. Fewer people need to buy food in a good harvest year. The harvest comes mainly from vlei areas and gardens. Donor food is important as a source of food in the household, but it is largely reduced in a good harvest year in the region and is not available to households that receive remittances.

\section{Scenario analysis}

Weights were given to the settings of the different scenarios (Table 3 ) by increasing the effect $(+1)$, reducing the effect $(-1)$, or setting it to half strength $( \pm 0.5)$. Graphical output of the FCM models for cash availability in the cattle-based (Fig. 7A) and crop-cattle-based livelihoods (Fig. 7B) cover the three scenarios Drought, Border, and Desirable in relation to the baseline scenario. After an initial transition period, the model outcomes stabilize at a certain value, which represents change in the output variable relative to the baseline scenario.

Table 3. Strength of the driver of livelihood functioning by scenario type as identified and described by local people and their stakeholders in southeastern Zimbabwe. 1 = very strong in relation to Baseline scenario.

\begin{tabular}{lcccc}
\hline \hline Driver & $\begin{array}{c}\text { Baseline } \\
\text { scenario } \dagger\end{array}$ & $\begin{array}{c}\text { Drought } \\
\text { scenario }\end{array}$ & $\begin{array}{c}\text { Border } \\
\text { scenario }\end{array}$ & $\begin{array}{c}\text { Desirable } \\
\text { scenario }\end{array}$ \\
\hline $\begin{array}{l}\text { Drought } \\
\text { Damage- } \\
\text { causing animals }\end{array}$ & 0 & 1 & 1 & -1 \\
$\begin{array}{l}\text { outside the park } \\
\text { Border } \\
\text { restrictions }\end{array}$ & 0 & 0 & 0 & -0.5 \\
Institutions & 0 & 0 & -1 & 1 \\
\hline
\end{tabular}

$\dagger$ The Baseline scenario is the reference point; all strengths are therefore set to zero.

The outcomes of the scenarios show the shortest, smoothest transition period for the cattle-based livelihood type (Fig. 7A). This signifies that the system is less complex and has weaker feedbacks than the crop-cattle-based livelihood type (Fig. 7B). After the transition period, the amount of cash in the cattlebased livelihood type stabilizes at around 0.3 in the Desirable scenario, which indicates a clear improvement in cash availability compared with the Baseline scenario and better cash availability compared with the Drought and Border scenarios. Although the uncertainty of the exact value of the 
Fig. 5. Fuzzy cognitive map of the crop-cattle-based livelihood type. Grey boxes are key indicators of the functioning of the livelihood; white boxes are variables; white circles are system drivers. Numbers given are influences between factors, where red font indicates negative relationships, and black font indicates positive relationships.

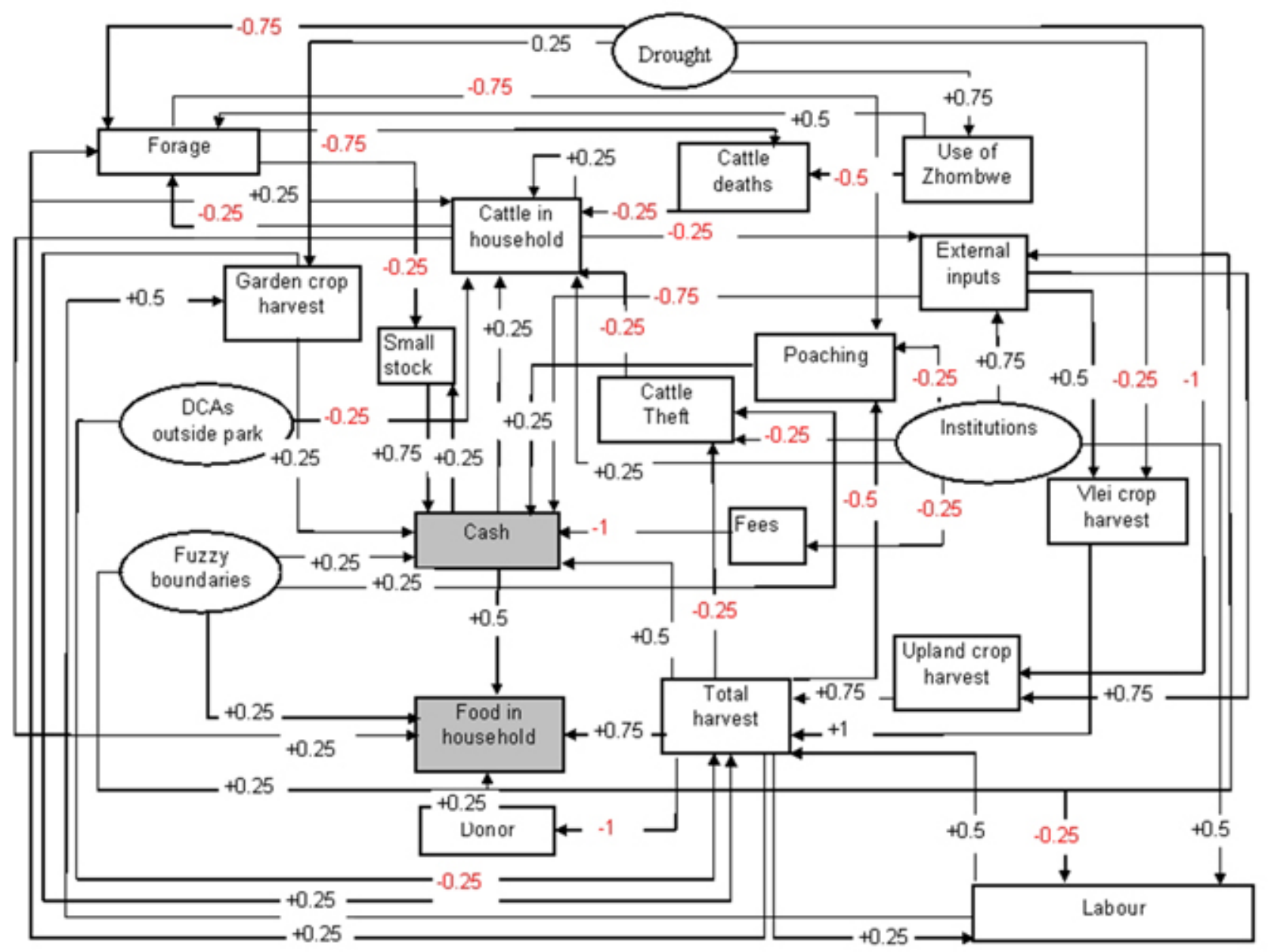

variable representing the amount of cash is large, signified by a wide band determined by the standard deviation of the 1000 runs performed in the sensitivity analysis, it is clear than an increase in the amount of cash is a robust outcome. Separate sensitivity analyses in which the weights of individual relationships were varied showed, not surprisingly, that the outcomes of the FCM analyses are especially dependent on the relationships with high weights and that changes in the values of these weights can have significant effects on the outcomes of the FCM analyses (results not shown). In the Drought scenario, the amount of cash becomes slightly better than in the Baseline scenario because farmers start selling cattle; thus, although the cash situation improves, the number of cattle decreases. In the Border scenario, it is more difficult to sell cattle (and prices go down); therefore, the households' cash situation deteriorates (Fig. 7A).

For the crop-cattle-based livelihood system, the different scenarios resulted in clear differences in cash availability (Fig. 7B). The outcomes of the crop-cattle-based livelihood system have a longer, haphazard transition period, which indicates that the system is more complex and has stronger feedbacks than the cattle-based livelihood. After the transition period, the amount of cash in the crop-cattle-based livelihood stabilizes at around 0.4 in the Desirable scenario, a clear improvement in the cash availability compared with the Baseline scenario. However, the Drought scenario (stability 
Fig. 6. Fuzzy cognitive map of the non-farm-based livelihood type. Grey boxes are key indicators of the functioning of the livelihood; white boxes are variables; white circles are system drivers. Numbers given are influences between factors, where red font indicates negative relationships, and black font indicates positive relationships.

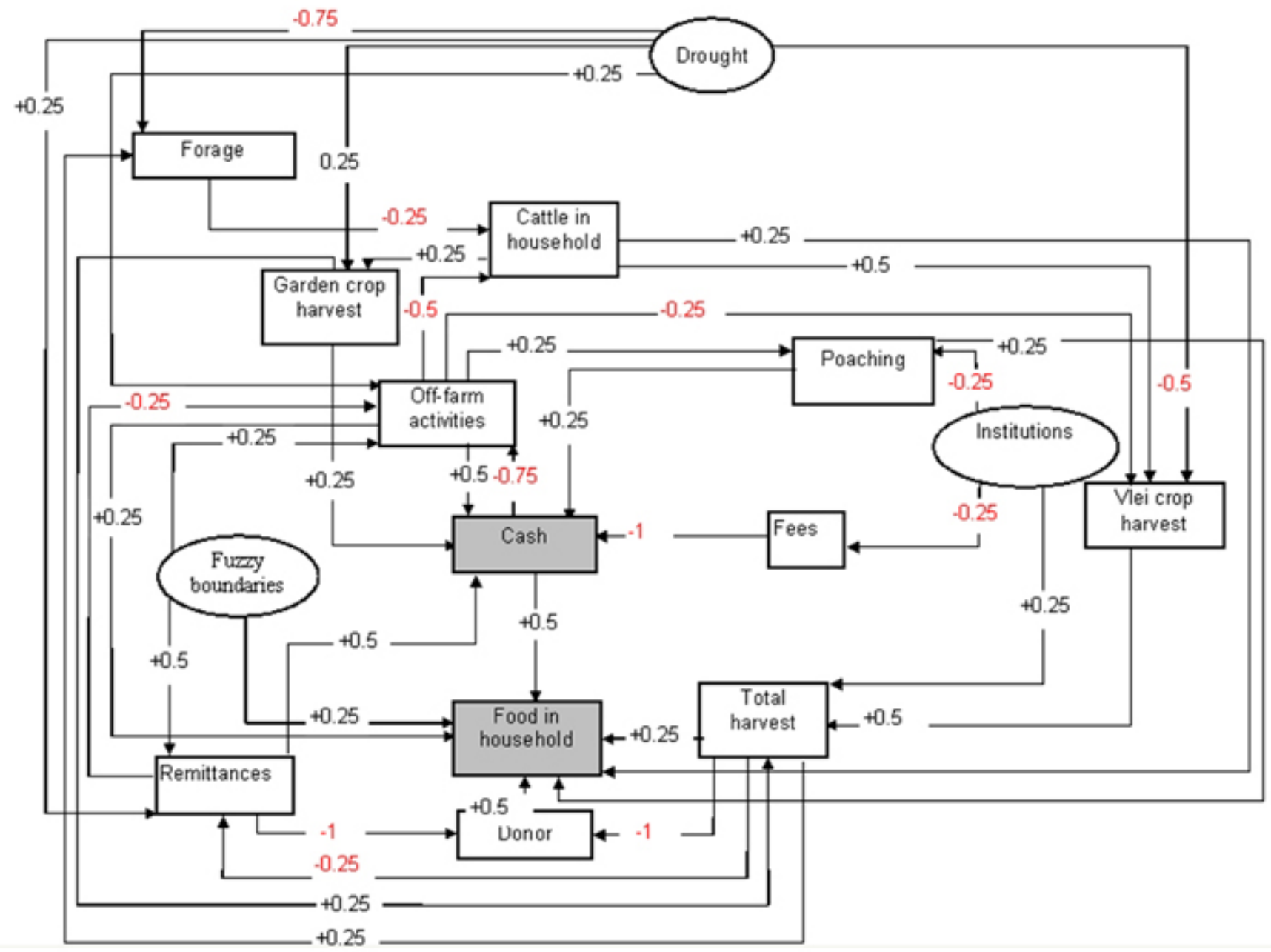

value of -0.35 ) and the Border scenario (stability value of -0.45 ) both show a clear reduction in available cash in the household. People rely on their garden for food and cash and also sell small livestock across the border. Thus, if the boundaries are closed, cash availability is further reduced. The difference between the stability values shows that the cropcattle-based livelihood has a more sensitive cash situation than the cattle-based livelihood.

To assess the overall effects of the scenarios on cash and food availability in the three livelihood types, the stabilized FCM outputs were determined for cash (Fig. 8A) and for food (Fig. $8 \mathrm{~B})$. The cash and food situation of the crop-cattle-based livelihood shows the most sensitivity to changing conditions. In all cases, food availability is strongly reduced in the Border scenario and strongly increased in the Desirable scenario. The
Border scenario was the worst scenario. The non-farm-based livelihood was least sensitive.

\section{DISCUSSION}

\section{Utility of fuzzy cognitive maps in livelihood analysis}

The framework presented here provides a graphical representation of the most important factors within the livelihoods and how these factors interact, and forms a basis to analyze the vulnerability of livelihoods to external changes. When using FCMs, the presence of certain factors and relationships have to be made concrete; therefore, the consequences of the representation chosen by the researcher based on the input of local people and stakeholders can be quantified. As such, FCMs can be used as a tool to represent the outcomes of a qualitative study of livelihoods and is a 
promising tool for formalizing systems knowledge. The process of data acquisition is intensive and time consuming due to the many steps involved and the broad consultation required during the early stages of FCM development.

Fig. 7. Output of the Drought, Border, and Desirable scenarios relative to the Baseline scenario. The $\mathrm{x}$-axis indicates the number of vector-matrix iterations; the length of the transition period, therefore, shows how many matrix multiplications are needed to take into account all of the feedbacks that exist within the system. The y-axis indicates the value of cash for cattle-based livelihoods (A) and cattlecrop-based livelihoods (B) relative to the Baseline scenario. Light gray bands represent the standard deviation of the ensemble scenario simulations in the sensitivity analysis.
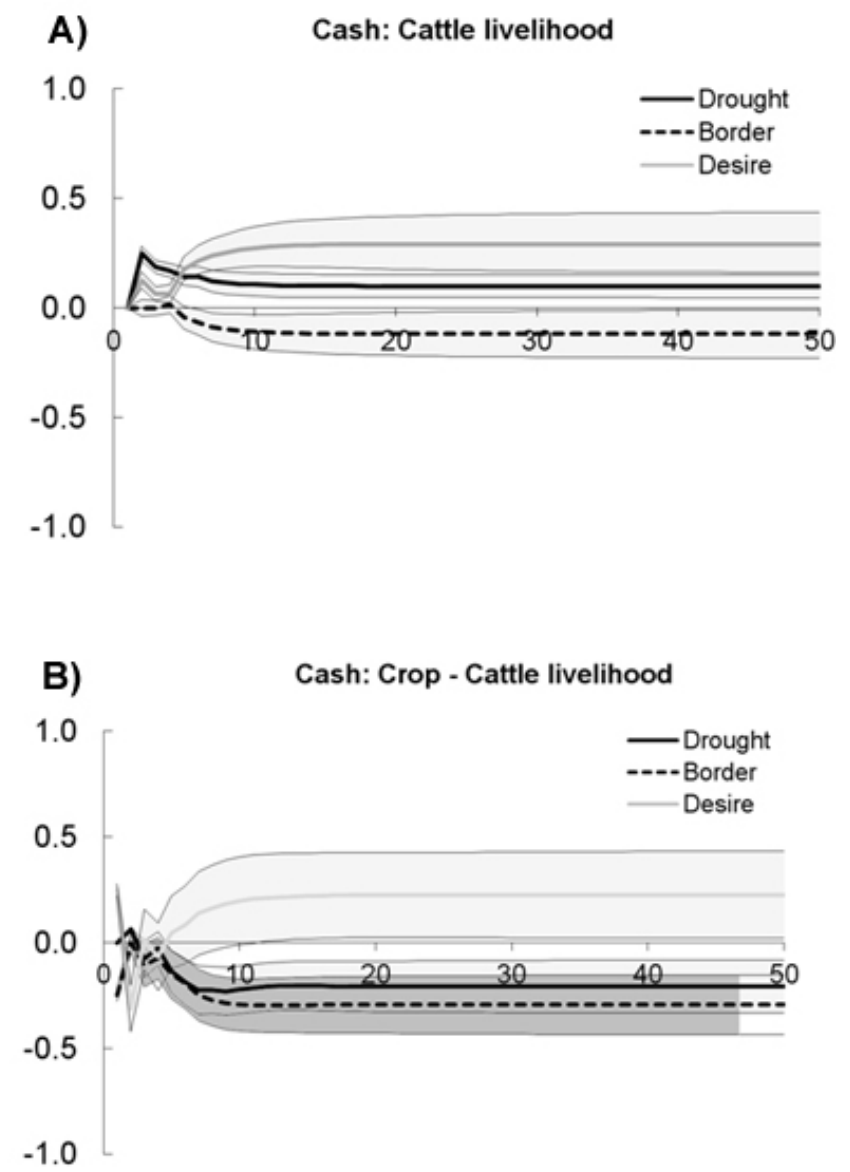

However, the iteration process makes the process sufficiently robust to generate a deeper understanding of the underlying factors determining livelihood types and their function, as observed by Van Vliet et al. (2010). Furthermore, the process requires close interaction among researchers, local people, and other stakeholders throughout. This enhances wider acceptance and ownership of the output by the intended users, who negotiate what is relevant and should be included. In this way, hidden knowledge is revealed and insights are gained that cannot be generated through working separately with individuals. A structured, semi-quantitative understanding of the system perceptions of a group of participants is one of the strengths of FCMs (Van Vliet et al. 2010). The interactions involved in developing FCMs present an opportunity for knowledge synthesis among stakeholders.

In the scenario analyses, FCMs indicate the direction in which the system will move given certain changes in the driving variables and also give an idea of the magnitude of system fluctuations after a disturbance. The sensitivity analysis shows how robust each of the outcomes is and is therefore useful in interpretation. Using FCMs in the scenario analysis was powerful because local people and other stakeholders could understand what was meant with each scenario and could relate to the outputs that were generated by the FCMs. By using peoples' experiences, we make use of trends relevant to the affected group targeted for analysis. FCMs also have weaknesses as tools for livelihood analysis (Özesmi and Özesmi 2004, Kok 2009). Simulation output of FCMs shows values only in relative terms. Because it is not a dynamic modeling tool, FCMs do not give insight on how long it takes the system to self-organize after disturbance, for example, when cattle die in a drought, or how long it takes the affected household to return to a normal way of life. These two limitations, i.e., being non-quantitative and non-dynamic, mean that FCMs can be used as an initial methodology to obtain insight into the behavior of the system and to indicate the equilibrium states of the system. It can be followed by more in-depth methods such as simulation modeling, with their associated data demands, if researchers want to have quantitative predictions of system behavior over time.

\section{Functioning and vulnerability of livelihoods in southeastern Zimbabwe}

In the case study presented, three key livelihood types were distinguished: cattle based, crop-cattle based, and non-farm based. The analyses showed that people in each livelihood are affected by hazards and react differently to resulting change: their vulnerability to change differs. For example, drought affects those depending on land resources more than those depending on the wider economy. Climate change is well documented as one of the major stressors of livelihood systems in semi-arid regions, but the analysis of vulnerability by the FCM method showed that issues of policy such as changing situations at borders can result in problems of greater magnitude than drought. In assessing the vulnerability of dryland pastoral systems to climate change, Dougill et al. (2010) found that qualitative issues of policy increase the vulnerability of poorer communal pastoralists. 
Fig. 8. Output of the Drought, Border, and Desirable scenarios for the cash situation (A) and food situation (B) of the different livelihood types in southeastern Zimbabwe lowveld. The $\mathrm{x}$-axis indicates the scenario. The y-axis indicates the value for cash (A) and food (B), relative to the Baseline scenario. Error bars indicate the standard deviation of the ensemble scenario simulations in the sensitivity analysis.
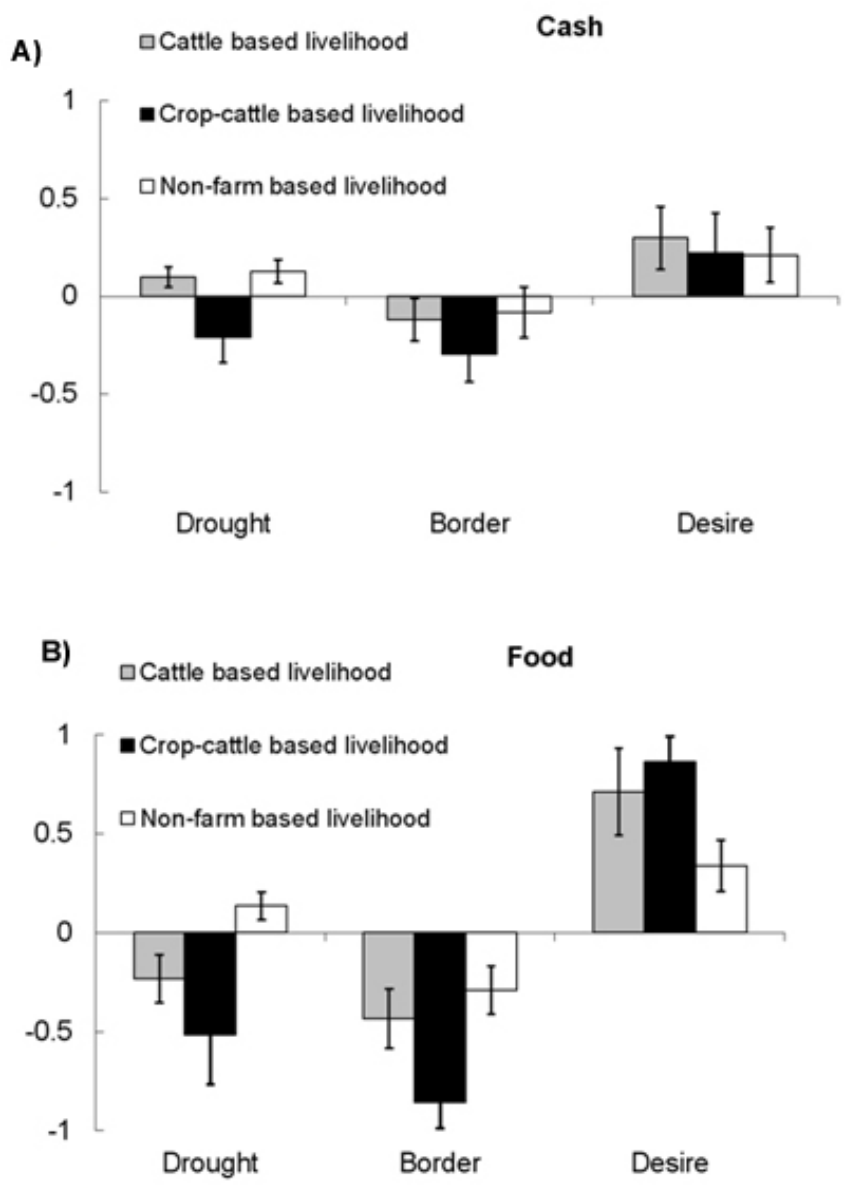

The assessment of livelihood vulnerability indeed brings insight into where policy makers can focus to improve if winwin situations, as proposed within the Great Limpopo Transfrontier Conservation Area, are to be realized.

It is generally accepted that cattle play a central role in the livelihoods of people living in marginal areas (Kinsey et al. 1998, Cumming 2005). Our results qualify this general statement. We found that in the southeastern lowveld, the number of cattle owned by a household is especially important. Herd size is not merely a sign of wealth, it is indicative of different production orientations. It is a defining variable for local people when asked to distinguish among different livelihoods. Having many cattle reduces a household's vulnerability, as it is a source of instant cash (plowing for cash, transportation, sale) without immediately jeopardizing the household's productive capacity in crop cultivation. The number of cattle spans used by a household determines the area that can be planted and how fast this can be done. Timely planting is a major factor in crop success in areas of marginal rainfall (Nyamudeza 1999). Besides cattle, polygamous marriages and large families are a sign of wealth, especially among the Shangaan speaking people, for whom large families are subsequently associated with a cattle-based livelihood.

\section{Livelihood vulnerability and drought}

In southeastern Zimbabwe, droughts are usually associated with outbreaks of livestock disease, especially tick-borne disease, lumping skin, and foot and mouth disease (FMD). Limited grazing outside the national park and dried-up watering points in the dry season and in drought years result in greater concentrations of animals on the limited resources. Consequently, the likelihood of buffalo-livestock interactions and disease transmissions, especially at watering points, increases. Buffalo are reservoirs for ticks and FMD; mixing of buffalo and cattle increases the chances for tick-borne diseases and FMD outbreaks. Whereas the more wealthy households can afford to invest in vaccination and treatment, poorer households rely more on traditional medicines, usually from protected shrubs and trees within Gonarezhou National Park. To reduce FMD outbreaks, movement of cattle into nonaffected areas is restricted; however, this depresses cattle sales and prices. Yet, as long as park and international boundary controls are limited, such effects of disease can be mitigated. Both traditional remedies for cattle diseases and cattle markets in Mozambique remain accessible, even though these options are illegal. Increased boundary controls thus increase vulnerability to drought, especially for poorer cattle owning households.

Whereas droughts deplete both food resources and cash in cattle-crop-based livelihoods, as food needs to be purchased, we found that cash and food availability tends to increase for non-farm livelihoods in times of drought. To understand this, one must appreciate the ways in which these livelihoods are linked to the wider economy. Their cash situation tends to improve because droughts induce these households to sell homemade crafts in nearby towns like Chiredzi, Beitbridge, and Masvingo, or abroad, or to seek temporary employment in Mozambique and South Africa, where household members often already work. The sale of crafts and labor outside the area enhances the improved food situation during drought. Whereas wealthy households with cattle-based livelihoods can raise cash to purchase food during drought, their food situation usually deteriorates as local supplies run out. Households with non-farm-based livelihoods are better positioned to deal with this situation. They purchase and 
transport food from further away. Truck deliveries of food from relatives working outside the country is but one example of how these livelihoods are embedded in wider networks of economic exchange.

FCMs proved to be a powerful tool, especially in the analyses of drought effects on livelihood functioning. Because of the incorporation of important feedback mechanisms like the sale of cattle, FCMs revealed the difference between indicators that are affected directly by drought (e.g., food selfsufficiency) and variables in which the buffering capacity of the household plays an important role (e.g., cash). Without the incorporation of feedbacks such as the sale of cattle, a livelihood analysis would overestimate the vulnerability of the livelihoods to drought. In this respect, FCM compares favorably to tools like Bayesian belief networks. If more quantitative information is available, other techniques like dynamic systems modeling can be used (e.g., Dougill et al. 2010), but it is attractive to start an analysis with a rapid and easily applicable tool like FCM, in which knowledge of both the "soft" and "hard" sides of science can be incorporated, followed by more in-depth assessment of the individual relationships.

In drought-prone areas, livelihoods dependent on crop cultivation are the most vulnerable. In the southeastern lowveld, such livelihoods face the additional risk of crop destruction by elephants and other wildlife. Crop-cattle-based households deploy several strategies to reduce these vulnerabilities. They crop larger areas, plant as much as they can in a short period of time, and with subsequent rains grow different drought-tolerant varieties of staple crops (maize and sorghum), practice dry-planting of sorghum to benefit from the first rains, reduce labor peaks at the beginning of the season, and replant up to three times if necessary. This was also observed and described by Nyamudeza (1999). The practice of continuous planting can, however, cause a shortage of planting material, increasing vulnerability in the next season. Thus, a preference for open pollinated maize varieties and limited boundary controls is understandable; the latter allows for purchase of seed from farmers across the border.

In the context of the development of the Great Limpopo Transfrontier Conservation Area, there is another reason why boundaries and their control are particularly relevant for understanding the vulnerability of livelihoods, especially crop-cattle-based ones. In addition to the above-mentioned strategies to reduce the risk of crop failure, crop farmers prefer to plant crops in different locations. Vlei areas are preferred locations because they are low lying and retain moisture longer than do upland areas. When drought wipes out a crop in upland fields, crops grown in the vleis still yield; conversely, when too much rainfall swamps vlei areas, better-draining upland areas produce yield.
A special kind of vlei in the southeastern lowveld of Zimbabwe is the Banyeni, or flood plains. In addition to water from rainfall and run-off, flood plains also receive water and alluvium when the river floods. An important area of Banyeni lies within the proposed Sengwe-Tchipise wildlife corridor, which would to connect Gonarezhou National Park directly to South Africa's Kruger National Park as part of the Great Limpopo Transfrontier Conservation Area. The wildlife corridor is likely to cause people in Sengwe to be displaced and will increase the presence of wildlife. People in Sengwe fear its development, as they are not compensated for destruction of crops by wildlife.

Crop-cattle-based livelihoods appear to be most vulnerable to such redefining of boundaries. Grazing areas will be reduced, and risk of wildlife-livestock disease transmission is likely to increase. Because the corridor is likely to reduce access to natural resources such as fish ponds, the fruit belt known locally as pfungwe, and bird sanctuaries, in addition to constraining (illegal) border crossings, this will negatively affect the dependence of non-farm-based livelihoods on nonagricultural sources of food and income in the area and across the border in South Africa.

\section{CONCLUSIONS}

FCMs successfully give semi-quantifiable information concerning the nature (increase or decrease) and magnitude by which a livelihood system changes under different scenarios. However, they do not explain the recovery path quantitatively in relation to time and pattern (e.g., how long it takes for cattle to return to desired numbers after a drought). We found that the interactive nature of FCMs reveals hidden knowledge and insights that improve the understanding of the complexity of livelihood systems in a way that is better appreciated by stakeholders. Analysis of vulnerability using the FCM method showed that issues of policy such as changing situations at borders can strongly aggravate vulnerability to climate change by increasing the drought sensitivity of livelihoods. FCMs can assist in effective communication platforms to involve communities in project participation and benefit sharing.

Responses to this article can be read online at: http://www.ecologyandsociety.org/voll6/iss4/art8/responses/

\section{Acknowledgments:}

This research was funded through the International Research and Education Fund (INREF) of Wageningen University through the Competing Claims on Natural Resources programme (see www.competingclaims.nl). 


\section{LITERATURE CITED}

Adger, W. N. 1999. Social vulnerability to climate change and extremes in coastal Vietnam. World Development 27 (2):249-269.

Adger, W. N. 2000. Social and ecological resilience: are they related? Progress in Human Geography 24(3):347-364. http:/ /dx.doi.org/10.1191/030913200701540465

Axelrod, R., editor. 1976. Structure of decision: the cognitive maps of political elites. Princeton University Press, Princeton, New Jersey, USA.

Berkes, F. 2007. Understanding uncertainty and reducing vulnerability: lessons from resilience thinking. Natural Hazards 41(2):283-295. http://dx.doi.org/10.1007/s11069-00 6-9036-7

Carley, K., and M. Palmquist. 1992. Extracting, representing, and analyzing mental models. Social Forces 70(3):601-636. http://dx.doi.org/10.2307/2579746

Castella, J.-C., Tran Ngoc Trung, and S. Boissau. 2005. Participatory simulation of land-use changes in the northern mountains of Vietnam: the combined use of an agent-based model, a role-playing game, and a geographic information system. Ecology and Society 10(1): 27. [online] URL: http:// www.ecologyandsociety.org/vol10/iss 1/art27/.

Chambers, R., and G. Conway. 1992. Sustainable rural livelihoods: practical concepts for the 21st century. IDS Discussion Paper 296, Institute of Development Studies, Brighton, UK.

Cooper, G. F. 1990. The computational complexity of probabilistic inference using Bayesian belief networks. Artificial Intelligence 42(2-3):393-405. http://dx.doi.org/10.1 016/0004-3702(90)90060-D

Crome, F. H. J., M. R. Thomas, and L. A. Moore. 1996. A novel Bayesian approach to assessing impacts of rain forest logging. Ecological Applications 6(4):1104-1123. http://dx.d oi.org/10.2307/2269595

Central Statistical Office. 2002. Provincial profile: Masvingo. Central Statistical Office, Harare, Zimbabwe.

Cumming, D. H. M. 2005. Wildlife, livestock and food security in the southeast lowveld of Zimbabwe. Pages 41-46 in S. A. Osofsky, S. Cleaveland, W. B. Karesh, M. D. Kock, P. J. Nyhus, and A. Yang, editors. Conservation and development interventions at the wildlifellivestock interface: implications for wildlife, livestock and human health. IUCN, Gland, Switzerland.

Cunliffe, R. N. 1993. Land use in the southeast lowveld. In B. Downie, editor. Gonarezhou National Park Management Planning Programme. Background Data Reports. Department of National Parks and Wildlife Management, Harare, Zimbabwe.
Dougill, A. J., E. D. G. Fraser, and M. S. Reed. 2010. Anticipating vulnerability to climate change in dryland pastoral systems: using dynamic systems models for the Kalahari. Ecology and Society 15(2): 17. [online] URL: http: //www.ecologyandsociety.org/vol15/iss2/art17/.

Dzingirai, V. 2003. The new scramble for the African countryside. Development and Change 34(2):243-264. http:// dx.doi.org/10.1111/1467-7660.00304

Eakin, H., and A. L. Luers. 2006. Assessing the vulnerability of social-environmental systems. Annual Review of Environment and Resources 31:365-394. http://dx.doi.org/10 .1146/annurev.energy.30.050504.144352

Ericksen, P. J. 2008. Conceptualizing food systems for global environmental change research. Global Environmental Change 18(1):234-245. http://dx.doi.org/10.1016/j.gloenvcha .2007 .09 .002

Folke, C. 2006. Resilience: the emergence of a perspective for social-ecological systems analyses. Global Environmental Change 16(3):253-267. http://dx.doi.org/10.1016/j.gloenvcha .2006 .04 .002

Folke, C., S. Carpenter, T. Elmqvist, L. Gunderson, C. S. Holling, and B. Walker. 2002. Resilience and sustainable development: building adaptive capacity in a world of transformations. Ambio 31(5):437-440.

Fraser, E. D. G. 2007. Travelling in antique lands: using past famines to develop an adaptability/resilience framework to identify food systems vulnerable to climate change. Climatic Change 83(4):495-514. http://dx.doi.org/10.1007/s10584-007 $\underline{-9240-9}$

Haas, T. C. 1991. Partial validation of Bayesian belief network advisory systems. AI Applications 5(4):59-71.

Heckerman, D. 1999. A tutorial on learning with Bayesian networks. In M. I. Jordan, editor. Learning in graphical models. MIT Press, Cambridge, Massachusetts, USA. http://d x.doi.org/10.1007/978-3-540-85066-3 3

Hermann, M. G. 1978. Review: political theory and methodology. American Political Science Review 72:1017-1018. http://dx.doi.org/10.2307/1955121

Ivy, P. 1981. A guide to soil coding and land capability classification for land use planners. Zimbabwe Department of Conservation and Extension, Ministry of Agriculture, Harare, Zimbabwe.

Janssen, M. A., M. L. Schoon, W. Ke, K. Börner. 2006. Scholarly networks on resilience, vulnerability and adaptation within the human dimensions of global environmental change. Global Environmental Change 16(3):240-252. http://dx.doi.o rg/10.1016/j.gloenvcha.2006.04.001

Kinsey, B., K. Burger, and J. W. Gunning. 1998. Coping with drought in Zimbabwe: survey evidence on responses of rural 
households to risk. World Development 26(1):89-110. http://d x.doi.org/10.1016/S0305-750X(97)00124-1

Kok, K. 2009. The potential of fuzzy cognitive maps for semiquantitative scenario development, with an example from Brazil. Global Environmental Change 19(1):122-133. http://d x.doi.org/10.1016/j.gloenvcha.2008.08.003

Kosko, B. 1986. Fuzzy cognitive maps. International Journal of Man-Machine Studies 24(1):65-75. http://dx.doi.org/10.1016/ S0020-7373(86)80040-2

Martínez-Santos, P., H. J. Henriksen, P. Zorrilla, and P. E. Martínez-Alfaro. 2010. Comparative reflections on the use of modelling tools in conflictive water management settings: the Mancha Occidental aquifer, Spain. Environmental Modelling \& Software 25(11):1439-1449. http://dx.doi.org/10.1016/j.en vsoft.2008.11.011

Mendoza, G. A., and R. Prabhu. 2006. Participatory modeling and analysis for sustainable forest management: overview of soft system dynamics models and applications. Forest Policy and Economics 9(2):179-196.

Newton, A. C., E. Marshall, K. Schreckenberg, D. Golicher, D. W. te Velde, F. Edouard, and E. Arancibia. 2006. Use of a Bayesian belief network to predict the impacts of commercializing non-timber forest products on livelihoods. Ecology and Society 11(2): 24. [online] URL: http://www.eco logyandsociety.org/vol11/iss2/art24/.

Nyamudeza. 1999. Agronomic practices for the low rainfall natural regions of Zimbabwe. Pages 49-63 in E. Manzungu, A. Senzanje, and P. van der Zaag, editors. Waterfor agriculture in Zimbabwe: policy and management options for the smallholder sector. University of Zimbabwe Publications, Harare, Zimbabwe.

O'Sullivan, D., and M. Haklay. 2000. Agent-based models and individualism: Is the world agent-based? Environment and Planning A 32(8):1409-1425. http://dx.doi.org/10.1068/a32140

Özesmi, U., and S. L. Özesmi. 2004. Ecological models based on people's knowledge: a multi-step fuzzy cognitive mapping approach. Ecological Modelling 176(1-2):43-64. http://dx.doi. org/10.1016/j.ecolmodel.2003.10.027

Pearl, J. 1993. Belief networks revisited. Artificial Intelligence 59(1-2):49-56. http://dx.doi.org/10.1016/0004-3702(93)90169$\underline{\mathrm{C}}$

Rattray, J. M., R. M. M. Cormack, and R. R. Staples. 1953. The vlei areas of S. Rhodesia and their uses. Rhodesia Agricultural Journal 50:465-483.

Scoones, I. 2009. Livelihoods perspectives and rural development. Journal of Peasant Studies 36(1):171-196. http ://dx.doi.org/10.1080/03066150902820503
Smid, J. H., D. Verloo, G. C. Barker, and A. H. Havelaar. 2010. Strengths and weaknesses of Monte Carlo simulation models and Bayesian belief networks in microbial risk assessment. International Journal of Food Microbiology 139 (Supplement):S57-S63. http://dx.doi.org/10.1016/j.ijfoodmic $\underline{\text { ro.2009.12.015 }}$

Spenceley, A. 2008. Requirements for sustainable naturebased tourism in transfrontier conservation areas: a southern African Delphi consultation. Tourism Geographies 10 (3):285-311. http://dx.doi.org/10.1080/14616680802236295

Subcommittee on Disaster Reduction. 2003. Reducing disaster vulnerability through science and technology. National Science and Technology Council, Washington, D. C., USA. [online] URL: http://www.sdr.gov/SDR_Report_Re ducingDisasterVulnerability2003.pdf.

Swendsen, J. D., and S. Norman. 1998. Preparing for community violence: mood and behavioral correlates of the second Rodney King verdicts. Journal of Traumatic Stress 11 (1):57-70. http://dx.doi.org/10.1023/A:1024405132015

Tolman, E. C. 1948. Cognitive maps in rats and men. Psychological Review 55(4):189-208. http://dx.doi.org/10.1037/ $\underline{\mathrm{h} 0061626}$

Toner, A. 2003. Exploring sustainable livelihoods approaches in relation to two interventions in Tanzania. Journal of International Development 15(6):771-781. http://dx.doi.org/1 $\underline{0.1002 / j i d .1030}$

Turner, B. L. II, R. E. Kasperson, P. A. Matson, J. J. McCarthy, R. W. Corell, L. Christensen, N. Eckley, J. X. Kasperson, A. Luers, M. L. Martello, C. Polsky, A. Pulsipher, and A. Schiller. 2003. A framework for vulnerability analysis in sustainability science. Proceedings of the National Academy of Sciences 100 (14):8074-8079. http://dx.doi.org/10.1073/pnas.1231335100

Van Vliet, M., K. Kok, and T. Veldkamp. 2010. Linking stakeholders and modellers in scenario studies: the use of fuzzy cognitive maps as a communication and learning tool. Futures 42(1):1-14. http://dx.doi.org/10.1016/j.futures.2009.08.005

Watts, M. J., and H. G. Bohle. 1993. The space of vulnerability: the causal structure of hunger and famine. Progress in Human Geography 17(1):43-67. http://dx.doi.org/10.1177/03091325 9301700103

Weinreb, G. E., T. C. Elston, and K. Jacobson. 2006. Causal mapping as a tool to mechanistically interpret phenomena in cell motility: application to cortical oscillations in spreading cells. Cell Motility and the Cytoskeleton 63(9):523-532. http: //dx.doi.org/10.1002/cm.20143

Wolfson, L. J., J. B. Kadane, and M. J. Small. 1996. Bayesian environmental policy decisions: two case studies. Ecological Applications 6(4):1056-1066. http://dx.doi.org/10.2307/2269590 